\title{
PENCAPAIAN INDIKATOR KELUARGA SEHAT DESA SAGULING KECAMATAN BAREGBEG KABUPATEN CIAMIS
}

\author{
Siti Rohimah ${ }^{1 *}$, Tika Sastraprawira ${ }^{1}$ \\ ${ }^{1}$ Program Studi Keperawatan Fakultas Ilmu Kesehatan Universitas Galuh Ciamis \\ Korespondensi e-mail: sitirohimahwibi@gmail.com \\ (Diterima 22 Oktober 2018; disetujui 15 -12-2018; dipublish 31-1-2019)
}

\begin{abstract}
ABSTRAK
Latar belakang. Upaya pencapaian prioritas pembangunan kesehatan 2015-219 dalam Program Indonesia Sehat dilaksanakan dengan mendayagunakan segenap potensi yang ada, baik dari pemerintah pusat, provinsi, kabupaten/kota, maupun masyarakat. Pembangunan kesehatan dimulai dari unit terkecil dari masyarakat yaitu keluarga. Pendekatan keluarga yang dimaksud dalam pedoman umum ini merupakan pengembangan dari kunjungan rumah oleh Puskesmas dan perluasan dari upaya Perawatan Kesehatan Masyarakat (Perkesmas), yang meliputi kegiatan berikut: 1) kunjungan keluarga untuk pendataan/pengumpulan data profil kesehatan keluarga dan peremajaan (updating) pangkalan datanya; 2) kunjungan keluarga dalam rangka promosi kesehatan sebagai upaya promotif dan preventif; 3) kunjungan keluarga untuk menindaklanjuti pelayanan kesehatan dalam gedung. Suatu keluarga dinyatakan sehat atau tidak digunakan beberapa penanda atau indikator. Dalam rangka pelaksanaaan Program Indonesia Sehat telah disepakati adanya dua belas indikator utama untuk penanda status kesehatan sebuah keluarga Adapaun tujuan dari penelitian ini adalah untuk mengetahui gambaran dasar pencapaian indikator keluarga sehat sebagai acuan dalam pengembangan pembangunan kesehatan desa binaan. Metoda.penelitian termasuk jenis penelitian penelitian deskriptif kuantitatif dengan teknik survey. Hasil penelitian menunjukan sebagian besar nilai Indeks Keluarga sehat Desa Saguling berada pada klasifikasi keluarga prasehat sebesar $80 \%$. Pencapaian indikator keluarga sehat di Desa Saguling mencapai 75, encapaian keikutsertaan keluarga menjadi anggota JKN sebesar 55, pencapaian indikator anggota keluarga tidak ada yang merokok dicapai sebesar $40 \%$, pencapaian penderita hipertensi melakukan pengobatan secara teratur dicapai sebesar $74 \%$, dan terdapat penderita hipertensi yang tidak melakukan pengobatan sebesar $26 \%$. pencapaian indikator keluarga mengikutu keluarga berencana (KB) mencapai $84 \%$. pencapaian indikator bayi mendapatkan imunisasi lengkap mencapai $82 \%$. Kesimpulan. Gambaran indeks keluarga sehat yang berada pada rentang tidak sehat, perlu upaya untuk meningkatkan kesehatan melalui pembinaan dalam pembangunan kesehatan dengan memaksimalkan pemberdayaan masyarakat.
\end{abstract}

Kata kunci: indeks keluarga sehat

\section{PENDAHULUAN}

Program Indonesia Sehat merupakan salah satu program dari agenda Nawa Cita, yaitu meningkatkan kualitas hidup manusia Indonesia dan menjadi program utama pembangunan kesehatan yang pencapaiannya direncanakan melalui rencana strategi Kementerian Kesehatan tahun 2015-2019, yang ditetapkan melalui Keputusan Menteri Kesehatan R.I Nomor HK.02.02/Menkes/52/2015 (Kemenkes
RI, 2016).

Sasaran dari program Indonesia Sehat adalah meningkatkan derajat kesehatan dengan menegakan 3 (tiga) pilar utamanya yatiu: 1) penerapan paradigm sehat; 2) penguatan pelayanan kesehatan; dan 3) pelaksanaan jaminan kesehatan nasional (JKN). Penerapan paradigma sehat dilakukan dengan strategi pengarusutamaan kesehatan dalam pembangunan, penguatan upaya promotif dan upaya preventif, serta pemberdayaan 
masyarakat. Penguatan pelayanan kesehatan dilakukan dengan strategi peningkatan akses pelayanan kesehatan, optimalisasi sistem rujukan dan peningkatan mutu menggunakan pendekatan continum of care dan intervensi berbasis risiko kesehatan. Pelaksanaan JKN dilakukan dengan strategi perluasan sasaran dan manfaat (benefit), serta kendali mutu dan biaya. Semua strategi yang dilakukan ditujukan unutk tercapainya keluarg-keluarga sehat (Kemenkes RI, 2016).

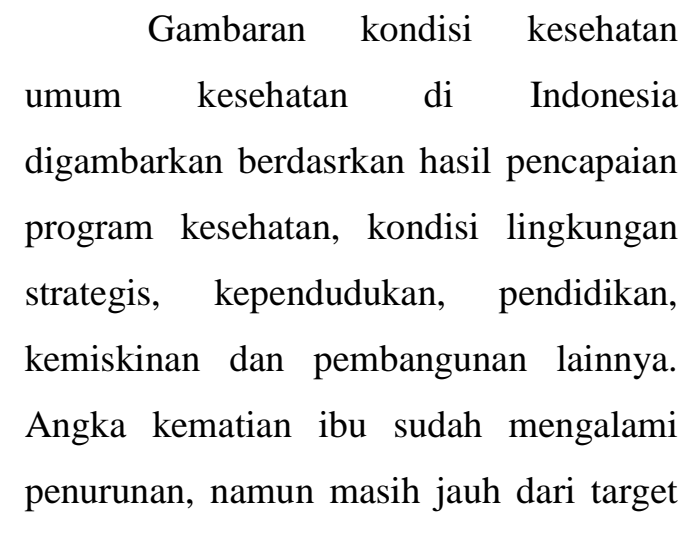
Millenium Development Goals (MGDs), meskipun pada taun 2015 telah terjadi peningkatan pertolongan persalinan oleh tenaga kesehatan. Angka Kematian Neonatal (AKN) tetap sama yakni 19/1000 kelahiran dalam 5 tahun terakhir. Gizi masyarakat underweight meningkat dari 18,4 menjadi $19,6 \%$, stunting meningkat dari $36,8 \%$ menjadi $37,2 \%$, Prevalensi obesitas meningkat pada usia dewasa. Penyakit menular fokus pada penyakit $H I V / A I D S$, tuberkuosa, malaria, demam berdarah, influenza dan flu burung, penyakit tidak menular cenderung terus meningkat, dan mengancam usia muda meliputi hipertensi, diabetes melitus, kanker dan penyakit paru obstruksi menahun (PPOK). Kesehata jiwa, masalah kesehatan jiwa sangat besar dan menimbulkan beban kesehatan yang signifikan, data Riskesdas tahun 2013 menunjukan prevalensi gangguan mental emosional (gejala-gejala depresi dan ansietas) sebesar 6\% untuk usia 15 tahun keatas, hal ini berarti lebih dari 14 juta jiwa menderita gangguan mental emosional di Indonesia. selain masalah diatas terdapat juga permasalahan yang haurs diperhatikan yaitu masalah kesehatan lingkungan.

Upaya pencapaian prioritas pembangunan kesehatan tahun 2015-2019 dalam program Indonesia ehat dilakukan dengan pemberdayaan seluruh potensi yang ada, baik dari pemerintah pusat, provinsi, kabupaten/kota, maupun masyarakat, pembangnan kesehatan dimulai dari unit terkecil masyarat yaitu keluarga (Kemenkes RI, 2016).

Keluarga adalah suatu lembaga yang merupakan satuan (unit) terkecil dari masyarakat, terdiri atas ayah, ibu, dan anak. Keluarga yang seperti ini disebut rumah tangga atau keluarga inti (keluarga batih),sedangkan keluarga yang anggotanya mencakup juga kakek dan atau nenek atau individu lain yang memiliki hubungan darah, bahkan juga tidak memiliki hubungan darah (misalnya pembantu rumah tangga), disebut keluarga luas (extended family). Keluarga merupakan unit terkecil dari masyarakat, maka derajat kesehatan rumah tangga atau keluarga menentukan derajat kesehatan masyarakatnya (Setiadi, 2008). Keluarga 
sebagai fokus dalam pelaksanaan program Indonesia Sehat, keluarga memiliki lima fugsi, yaitu: 1) fungsi afektif (the affective function) adalah fungsi keluarga yang utama untuk mengajarkan segala sesuatu untuk mempersiapkan anggota keluarga berhubungan dengan orang lain, fungsi ini dibutuhkan untuk perkembangan individu dan psikososial anggota keluarga; 2) fungsi sosialisasi, yaitu proses perkembangan dan perubahan yang dilalui individu yang menghasilkan interaksi social dan belajar berperan dalam lingkungan sosialnya, fungsi ini berguna untuk membina sosialisasi anak, membentuk norma-norma tingkah laku sesuai dengan perkembangan anak dan meneriskan nilai-nilai budaya keluarga; 3) fungsi reproduksi (the reproduction function) adalah fungsi mempertahankan generasi dan menjaga kelangsungan keluarga; 4) fungsi ekonomi (the economic function) yatu keluarga berfungsi untuk emenuhi kebutuhan keluarga secara ekonomi dan tempat dalam mengembangkan kemampuan individu meningkatkan penghasilan agar memenuhi kebutuhan keluarga; 5) fungsi perawatan atau pemeliharaan kesehatan (the health care function) adalah untuk mempertahankan keadaan kesehatan anggota keluarga agar tetap memiliki produktivitas yang tinggi, fungsi ini dikembangkan menjadi tugas keluarga di bidang kesehatan.

Tugas-tugas keluarga dalam pemeliharaan kesehatan adalah: 1) mengenal gangguan perkembangan kesehatan setiap anggota keluarganya; 2) mengambil keputusan untuk tindakan kesehatan yang tepat; 3) memberian perawatan kepada anggota keluarga yang sakit; 4) mempertahankan suasana rumah yang menguntungkan untuk kesehatan dan perkembangan kepribadian anggota keluarganya; 5) mempertahankan hubungan timbal balik antara keluarga dan fasilitas kesehatan.

Derajat kesehatan keluarga sangat ditentukan oleh PHBS dari keluarga tersebut. Inti dari pengembangan desa dan kelurahan adalah memberdayakan keluarga-keluarga agar mampu mempraktikkan PHBS. Perilaku Hidup Bersih dan Sehat adalah sekumpulan perilaku yang dipraktikkan atas dasar kesadaran sebagai hasil pembelajaran, yang menjadikan seseorang, keluarga, kelompok atau masyarakat mampu menolong dirinya sendiri (mandiri) di bidang kesehatan dan berperan aktif dalam mewujudkan kesehatan masyarakat (Kemenkes RI, 2016).

Pembangunan

keluarga, sebagaimana dimaksud dalam UndangUndang Nomor 52 Tahun 2009 tentang Perkembangan Kependudukan dan Pembangunan Keluarga serta UndangUndang Nomor 23 Tahun 2014 tentang Pemerintahan Daerah, adalah upaya mewujudkan keluarga berkualitas yang hidup dalam lingkungan yang sehat. Pemerintah pusat dan pemerintah daerah menetapkan kebijakan pembangunan keluarga melalui pembinaan ketahanan 
dan kesejahteraan keluarga, untuk mendukung keluarga agar dapat melaksanakan fungsinya secara optimal. (Kemenkes RI, 2016).

Pendekatan keluarga yang dimaksud dalam pedoman umum ini merupakan pengembangan dari kunjungan rumah oleh Puskesmas dan perluasan dari upaya Perawatan Kesehatan Masyarakat (Perkesmas), yang meliputi kegiatan berikut: 1) kunjungan keluarga untuk pendataan/pengumpulan data profil kesehatan keluarga dan peremajaan (updating) pangkalan datanya; 2) kunjungan keluarga dalam rangka promosi kesehatan sebagai upaya promotif dan preventif; 3) kunjungan keluarga untuk menindaklanjuti pelayanan kesehatan dalam gedung (Kemenkes RI, 2016)..

Satu keluarga adalah satu kesatuan keluarga inti (ayah, ibu, dan anak) sebagaimana dinyatakan dalam kartu keluarga. Keluarga yang terdapat kakek dan atau nenek atau individu laindalam satu rumah tangga, maka rumah tangga tersebut dianggap terdiri lebih dari satu keluarga (Suprajitno, 2016). Suatu keluarga dinyatakan sehat atau tidak digunakan beberapa penanda atau indikator. Dalam rangka pelaksanaaan Program Indonesia Sehat telah disepakati adanya dua belas indikator utama untuk penanda status kesehatan sebuah keluarga. Kedua belas indikator utama tersebut adalah sebagai berikut: 1) keluarga mengikuti program
Keluarga Berencana (KB); 2) ibu melakukan persalinan di fasilitas kesehatan; 3) bayi mendapat imunisasi dasar lengkap; 4) bayi mendapat air susu ibu (ASI) eksklusif; 5) balita mendapatkan pematauan pertumbuhan; 6) penderita tuberkulosis paru mendapatkan pengobatan sesuai standar; 7) penderita hipertensi melakukan pengobatan secara teratur; 8) penderita gangguan jiwa mendapatkan pengobatan dan tidak ditelantarkan; 9) anggota keluarga tidak ada yang merokok; 10) keluarga sudah menjadi anggota Jaminan Kesehatan Nasional (JKN); 11) keluarga mempunyai akses sarana air bersih; 12) keluarga mempunyai akses atau menggunakan jamban sehat. Indikator tersebut, dilakukan penghitungan Indeks Keluarga Sehat (IKS) dari setiap keluarga, sedangkan keadaan masing- masing indikator mencerminkan kondisi PHBS dari keluarga yang bersangkutan. Pelaksanaan Program Indonesia Sehat dengan Pendekatan Keluarga dapat dilakukan oleh Puskesmas bekerjasama dengan berbagai pihak termasuk pihak akdemisi akan berjalan dengan baik, bila dilaksanakan dengan langkah-langkah persiapan yang meliputi: 1) sosialisasi,; 2) pengorganisasian; 3) pembiayaan; dan 4) persiapan pendataan (Kemenkes RI, 2016).

Berdasarkan uraian diatas dianggap penting untuk berpartisipasi dalam rangka menunjang pembangunan kesehatan melalui pencapaian program Indonesia Sehat dengan pendekatan 
keluarga dengan langkah-langkah manajemen pendekatan keluarga yang diawali dengan survey pendataan keluarga dengan instrument indicator keluarga sehat sebagai dasar dalam pembinaan keluarga diwilayah binaan Fakultas Ilmu Kesehtan Universitas Galuh ciamis, data hasil survey dapat dimanfaatkan sebagai data dasar dan informasi profil kesehatan keluarga untuk pengorganisasian/pemberdayaan

masyarakat dan manajemen

Puskesmas.

\section{METODE PENELITIAN}

Dalam penelitian dilakukan survey berbasis komunitas dengan teknik wawancara, observasi dan pemeriksaan untuk mendapatkan gambaran data pencapaian indikator keluarga sehat. Data dikumpulkan sebanyak 307 keluarga dari jumlah populasi 1.336 kepala keluarga (KK), yang terbagi menjadi tiga dusun cakupan wilayah Desa Baregbeg, yaitu Dusun Kelewih, Dusun Saguling Kolot, dan Dusun Desa. Penelitian dilakukan di wilayah desa Saguling mulai November 2017 sampai dengan bulan Maret 2018. Data yang dikumpulkan dinalisa dengan cara analisa univariat untuk memberikan gambbaran pencapaian indikator indeks keluarga sehat di Desa Saguling, kecamatan Baregbeg Kabupaten Ciamis.

\section{HASIL DAN DISKUSI}

1. Distribusi penduduk Desa Saguling berdasarkan umum

Hasil penelitian mengenai distribusi penduduk berdasarkan kriteria usia di wilayah Desa Saguling Kecamatan Baregbeg Kabupaten Ciamis tahun 2019 dapat dilihat pada grafik di bawah ini

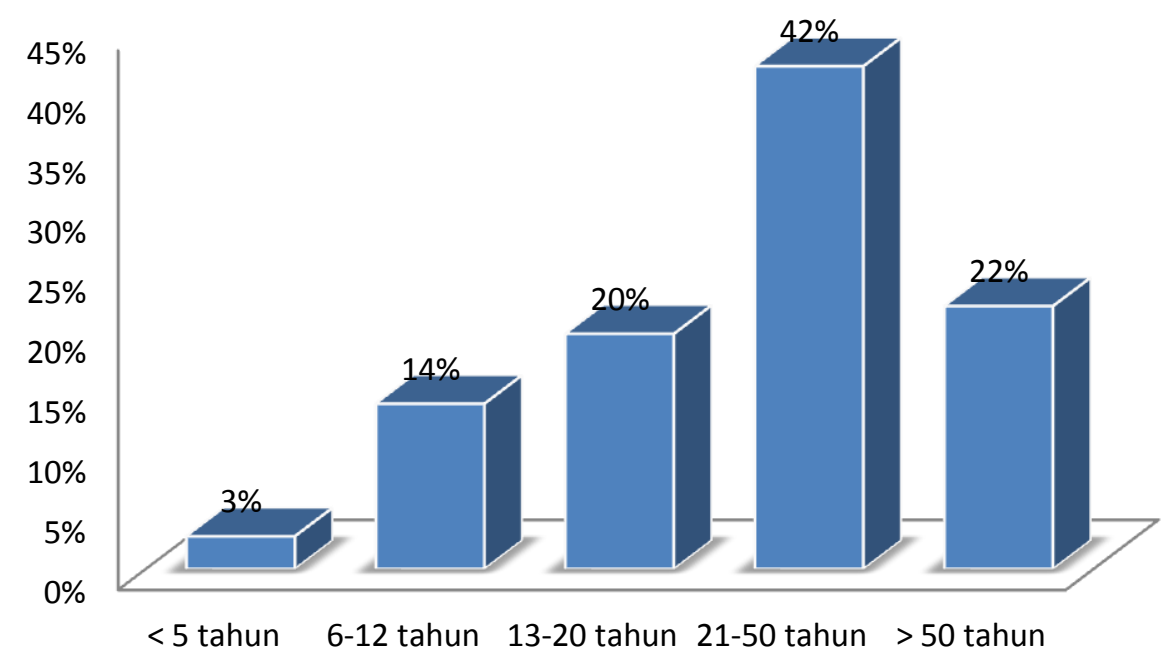

Data pada grafik diatas menunjukkan bahwa sebagian besar responden berada pada rentang 21-25 tahun sebanyak $417(42 \%)$, usia > 50 tahun sebanyak 218 orang (22\%).

2. Distribusi penduduk Desa Saguling berdasarkan Jenis Kelamin 
Hasil penelitian mengenai distribusi penduduk berdasarkan jenis kelamin di wilayah dusun desa Kecamatan
Baregbeg Kabupaten Ciamis tahun 2019 dapat dilihat pada grafik di bawah ini

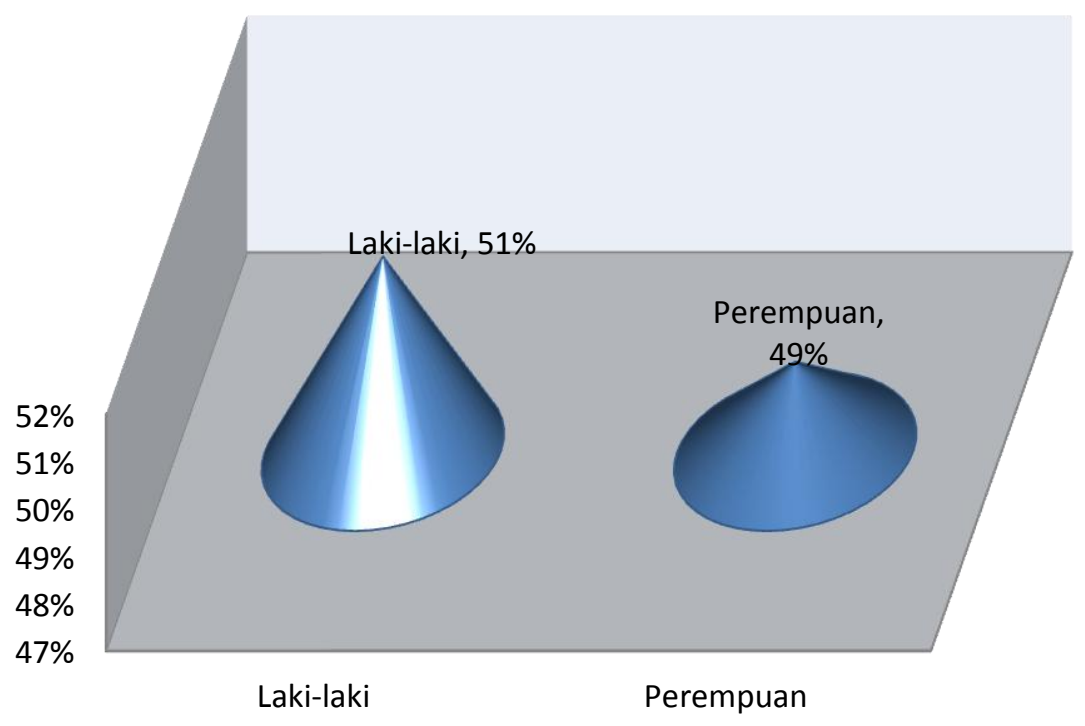

Data pada grafik diatas menunjukkan bahwa sebagian besar responden Hasil penelitian mengenai distribusi berjenis kelamin laki-laki sebanyak 508 (51\%), perempuan 486 orang (49\%).

3. Distribusi penduduk Desa Saguling penduduk berdasarkan tingkat pendidikan di wilayah Desa Saguling Kecamatan Baregbeg Kabupaten Ciamis tahun 2019 dapat dilihat pada berdasarkan Pendidikan

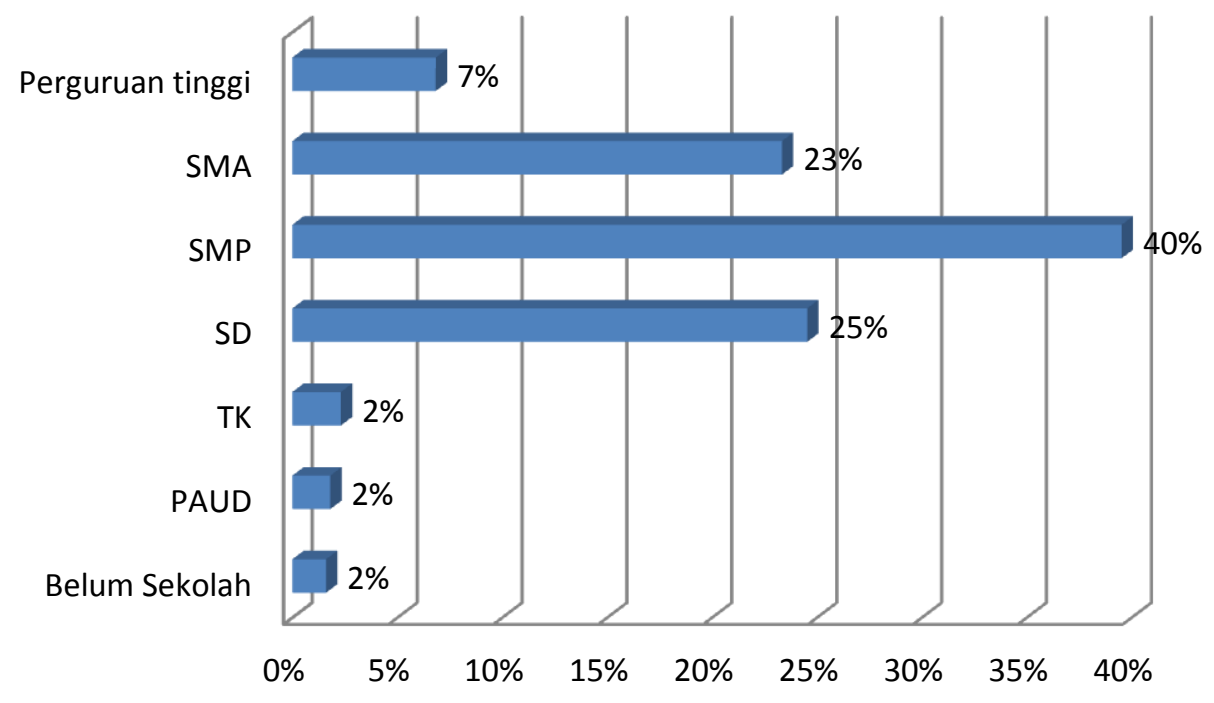

Data pada grafik diatas menunjukkan responden berpendidikan SMP bahwa sebagian besar pendidikan sebanyak 393 (40\%). 
4. Indeks Kesehatan Keluarga Dusun Saguling

Hasil penelitian mengenai nilai indeks kesehata keluarga di wilayah Dusun
Saguling Kecamatan Baregbeg Kabupaten Ciamis tahun 2019 dapat dilihat pada grafik di bawah ini

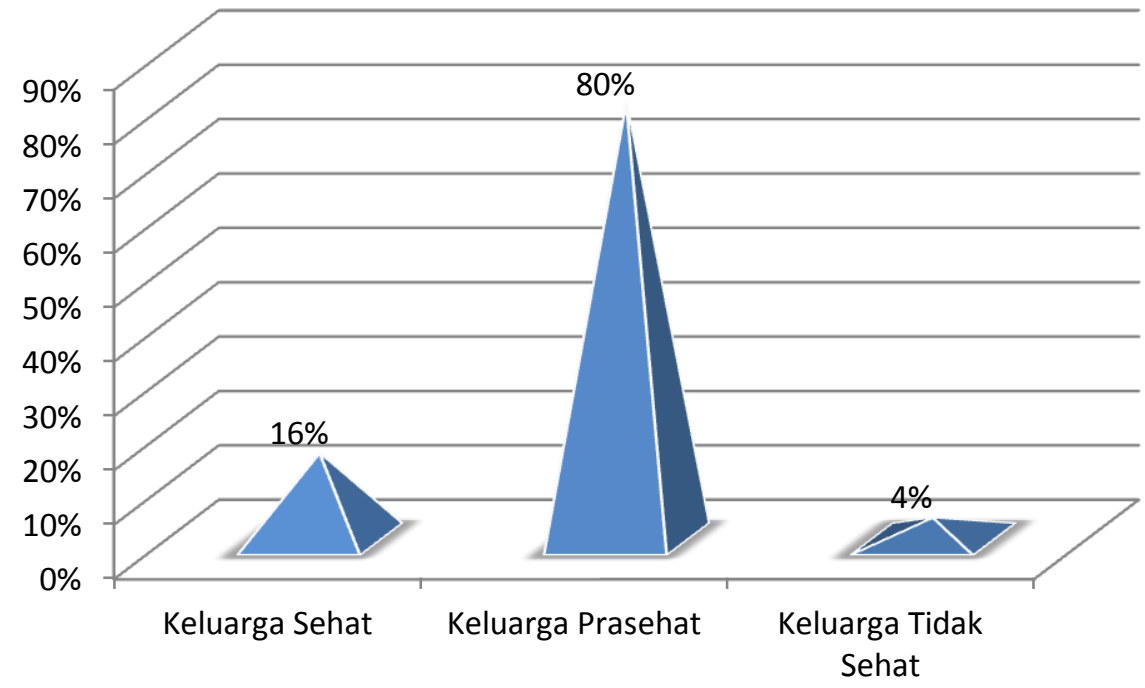

Data pada grafik diatas menunjukkan bahwa sebagian besar nilai Indeks Keluarga sehat Dusun Saguling berada pada klasifikasi keluarga prasehat sebesar $80 \%$

5. Indeks Kesehatan Keluarga Dusun
Hasil penelitian mengenai nilai indeks kesehata keluarga di wilayah Dusun Kelewih Kecamatan Baregbeg Kabupaten Ciamis tahun 2019 dapat dilihat pada grafik di bawah ini

Kelewih

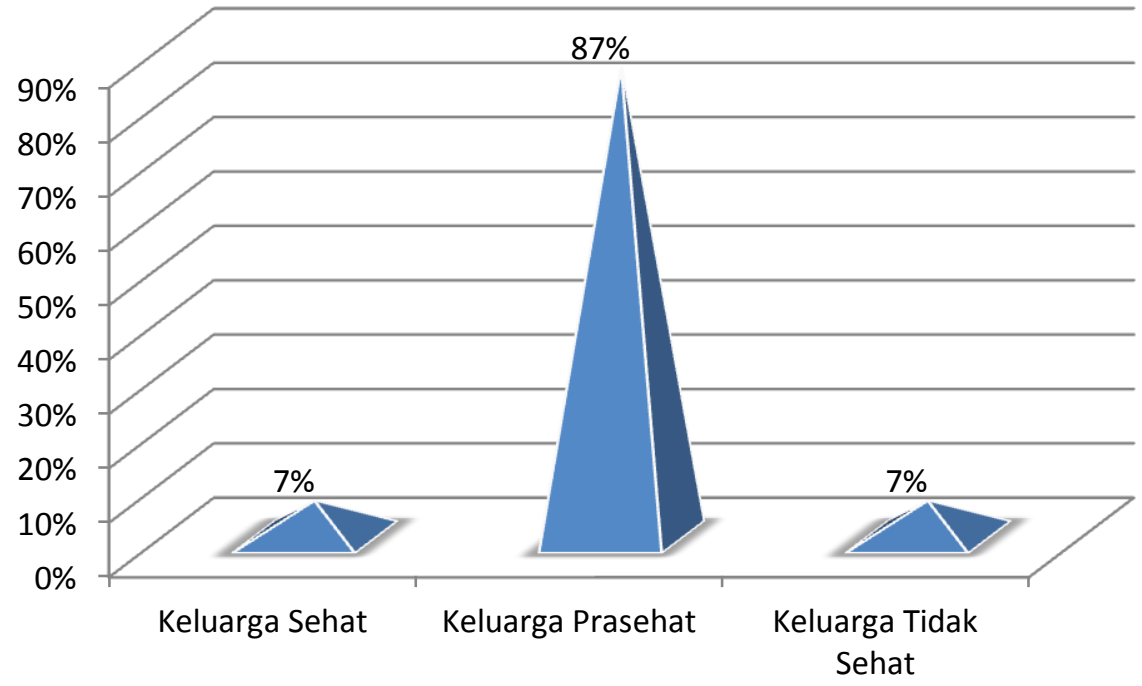

Data pada grafik diatas menunjukkan

bahwa sebagian besar nilai Indeks 
Keluarga sehat Dusun Kelewih berada

pada klasifikasi keluarga prasehat sebesar $87 \%$.

6. Indeks Kesehatan Keluarga Dusun Desa
Hasil penelitian mengenai nilai indeks kesehatan keluarga di wilayah Dusun Desa Kecamatan Baregbeg Kabupaten Ciamis tahun 2019 dapat dilihat pada grafik di bawah ini

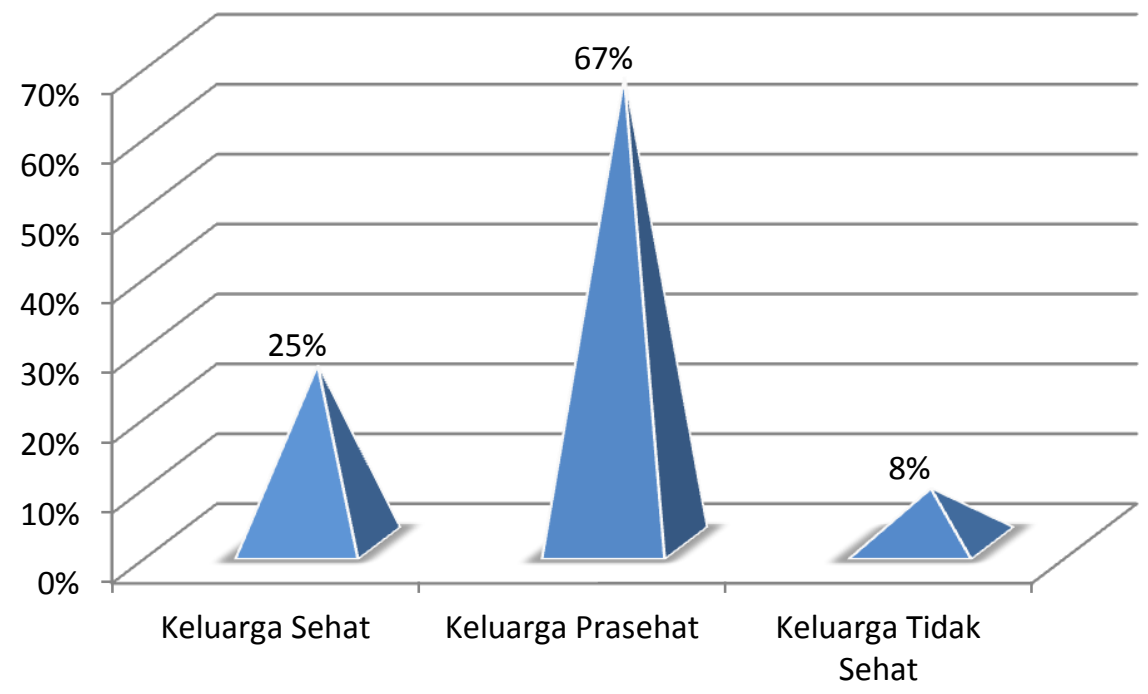

Data pada grafik diatas menunjukkan bahwa sebagian besar nilai Indeks Keluarga sehat Dusun Desa berada pada klasifikasi keluarga prasehat sebesar $67 \%$.

7. Indeks Kesehatan Keluarga Desa
Hasil penelitian mengenai nilai indeks kesehata keluarga di wilayah DesaSaguling Kecamatan Baregbeg Kabupaten Ciamis tahun 2019 dapat dilihat pada grafik di bawah ini

Saguling

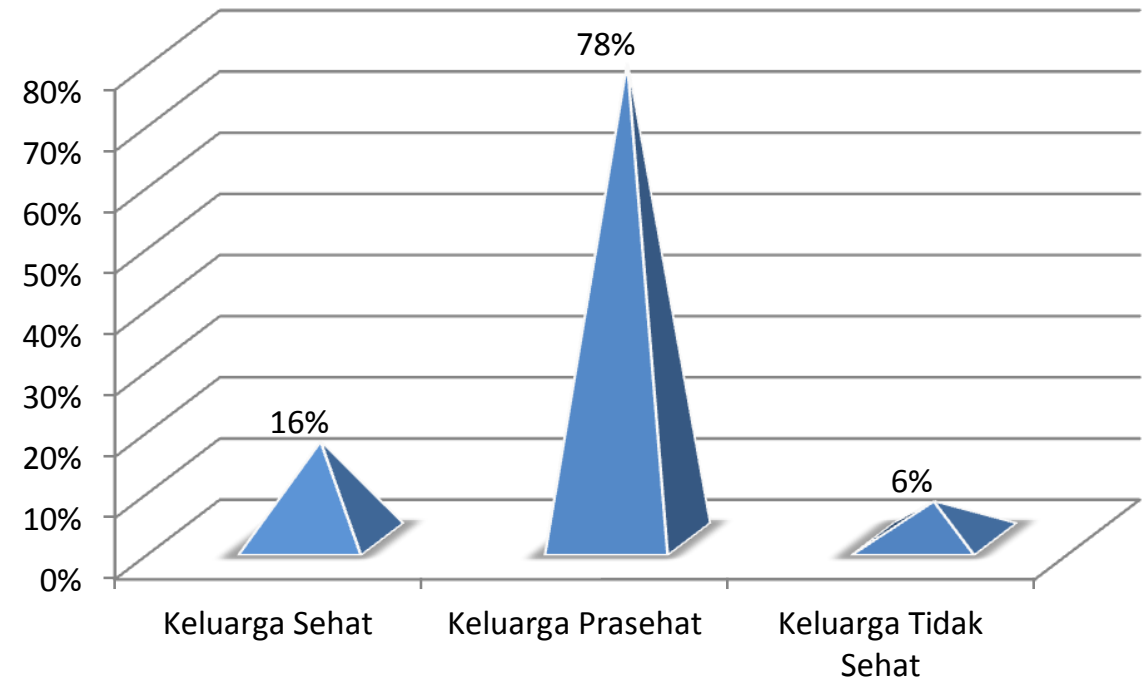


Data pada grafik diatas menunjukkan bahwa secara keseluruhan sebagian besar nilai Indeks Keluarga sehat Desa Saguling berada pada klasifikasi keluarga prasehat sebesar $80 \%$

8. Pencapaian Indikator Keluarga Sehat Desa Saguling
Volume : 1-Nomor : 1 Tahun : 2019 Hasil penelitian mengenai pencapaian kriteria kesehatan keluarga di wilayah Desa Saguling Kecamatan Baregbeg Kabupaten Ciamis tahun 2019 dapat dilihat pada grafik di bawah ini

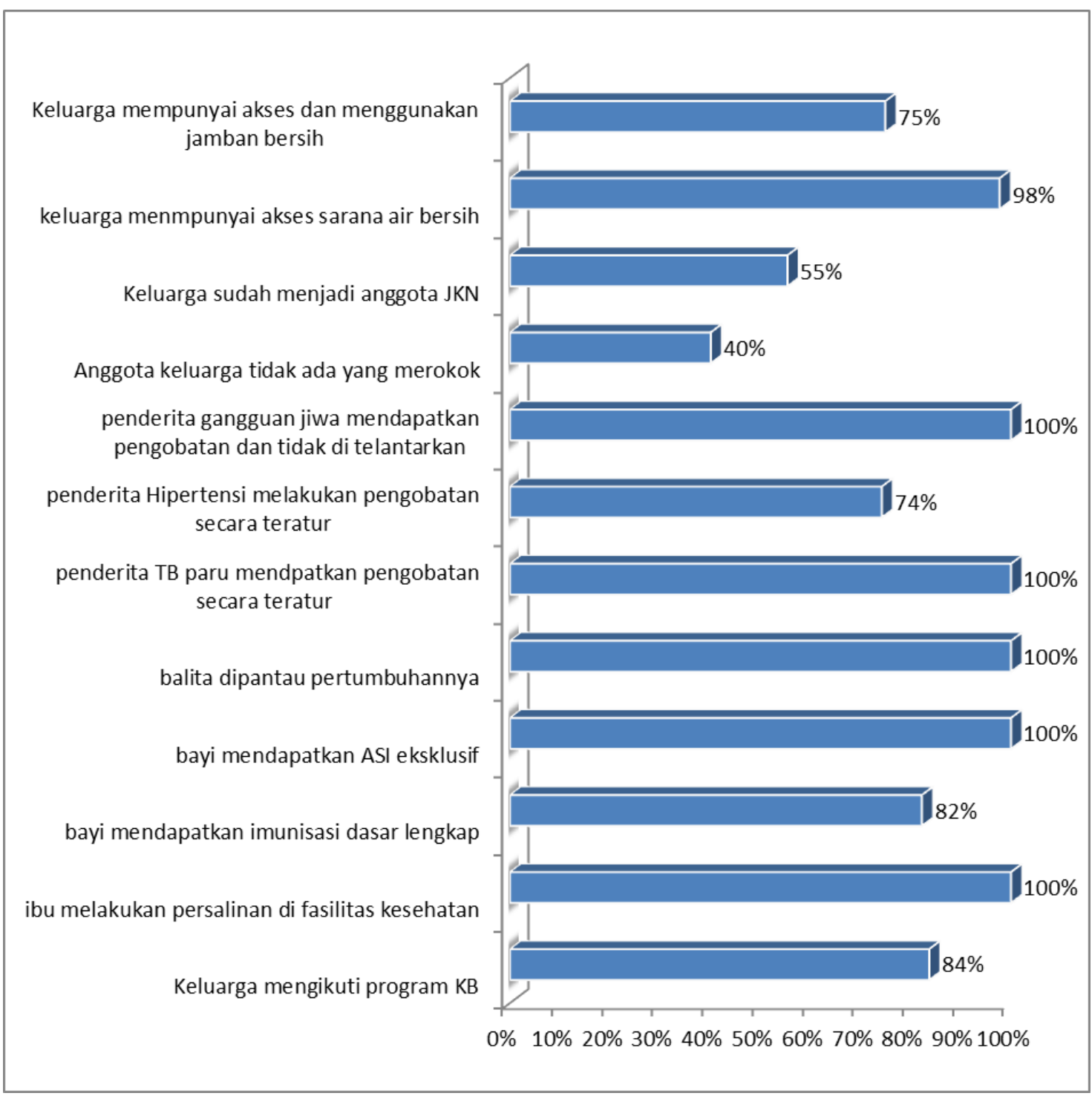

Data pada grafik diatas menunjukkan bahwa baru enam indikator keluarga sehat yang tercapai 90\%. indikator lainnya masih dibawah $90 \%$. Pembahasan masing-masing ketidaktercapian indikator keluarga sehat adalah sebagai berikut: a. Keluarga mempunyai akses dan menggunakan jamban sehat Pencapaian indicator keluarga sehat di Desa Saguling mencapai $75 \%$, artinya masih ada $25 \%$ keluarga yang tidak memiliki akses dan menggunakan jamban 
sehat.berdasarkan konsep dan definisi Milenium Development

Goals (MDGs) dan dilanjutkan dengan Sustainable Development Goals (SDGs), rumah tangga dikatakan memiliki akses sanitasi layak apabila fasilitas sanitasi yang digunakan memenuhi syarat kesehatan antara lain dilengkapi dengan leher angsa, tankiseptik (septic tank), Sistem Pengolahan Air Limbah (SPAL) yang digunakan sendiri atau bersama. Persentase rumah tangga di Indonesia yang memiliki akses terhadap sanitasi layak tahun 2013 yaitu $60,05 \%$ dan meningkat pada tahun 2014 menjadi $61,08 \%$ dan pada tahun 2015 meningkat menjadi 62,14\% (Kemenkes RI, 2016). Air bersih dan sanitasi layak adalah kebutuhan dasar manusia. Salah sat poin dalam tujuan pembangunan berkelanjutan SDGs pada sector lingkungan hidup adalah memastikan masyarakat mencapai akses universal air bersih dan sanitasi dasar yaitu jamban sehat. Fera dan Rizka melakukan penelitian tentang determinan kepemilikan jamban sehat, hasil penelitiannya menyimpulkan bahwa ada hubungan yang berakna antara kepemilikan jamban sehat dengan tingkat pendidikan, pengetahuan, sikap dan pendapatan keluarga. Ketidaktercapaian indicator penggunaan jamban sehat dalam hasil penelitian ini kemungkinan ada keterkaitan dengan dengan tingkat pendidikan yang sebagian besar tingkat pendidikan responden adalah SMP. Pengetahuan merupakan domain yang sangat penting dalam membentuk tindakan seseorang, sebab dari pengalaman dan hasil penelitian, ternyata perilaku yang didasari oleh pengetahuan akan lebih langgeng daripada perilaku yang tidak didasari oleh pengetahuan. Pengetahuan yang dimiliki oleh individu merupakan salah satu faktor yang menentukan untuk mencari dan meminta upaya pelayanan kesehatan. Semakin tinggi pengetahuan individu tentang akibat yang ditimbulkan oleh suatu penyakit, maka makin tinggi upaya pencegahan yang dilakukan (Gerungan dalam Dharma, 2014).

b. Keluarga sudah menjadi anggota JKN

Hasil penelitian menunjukan bahwa pencapaian keikutsertaan keluarga menjadi anggota JKN sebesar 55\%, dan 45\% keluarga belum menjadi anggota JKN. Jaminan Kesehatan Nasional $(\mathrm{JKN})$ di Indonesia dimulai sejak 1 Januari tahun 2014 telah memberikan andil yang besar terhadap reformasi system pelayanan dan pembiayaan kesehatan di Indonesia. 
Sebagaimana diamanatkan

Undang-Undang, JKN diharapkan secara bertahap dapat menjadi tulang punggung untuk mencapai Universal

Health

Coverage di Tahun 2019. Hingga saat ini telah banyak dilakukan berbagai penelitian yang bertujuan mengevaluasi program JKN yang diharapkan dapat memberi masukan dalam upaya perbaikan kedepan (UU, 2004). Hasl penelitian yang dilakukan Irwnady tahun 2015 tentang evaluasi pelaksanaan program JKN di Indonesia menunjukan bahwa bahwa selama penerapan JKN ditemui beberapa kendala yang dihadapi yakni pada awal pelaksanaan masih terkendala dengan belum tersedinya beberapa regulasi dan juknis terkait implementasi JKN, sosialisasi teknis program ke fasilitas pelayanan kesehatan baik Puskesmas dan RS masih rendah, disamping itu masih kurang siapnya beberapa RS dalam memenuhi persyaratan kredensial yang ditetapkan BPJS, besaran tarif $I N A C B G$ yang dirasa kurang tepat bagi RS serta klaim RS yang terlambat. Hasil penelitian lain juga memperlihatkan untuk tingkat kepuasan pasien BPJS di salah satu RS telah berada pada kategori baik yakni $\quad 87,7 \%$. Kesimpulannya Selama penerapan Program JKN di
Indonesia telah ditemukan beberapa faktor pendukung dan penghambat pelaksanaan program JKN. Oleh karena itu diperlukan perbaikan secara terus menerus terhadap pelaksanaan program JKN demi pencapaian Univeral Health Coverage pada Tahun 2019 dengan meningkatkan kuantitas dan kualitas pelaksanaan penelitian dalam mengevaluasi pelaksanaan JKN di Indonesia

c. Anggota keluarga tidak ada yang merokok

Indicator anggota keluarga tidak ada yang merokok dicapai sebesar $40 \%$, artinya $60 \%$ anggota keluarga adalah perokok. Indonesia menduduki peringkat ke-3 dengan jumlah perokok terbesar di dunis setelah China dan India (WHO,2008). Pada tahun 2007, Indonesia menduduki peringkat ke 5 konsumen rokok terbesar setelah China, Amerika Serikat, Rusia dan Jepang. Pada tahun yang sama, Riset Kesehatan Dasar menyebutkan bahwa penduduk berumur di atas 10 tahun merokok sebesar 29,2\% dan angka tersebut meningkat sebesar $34,7 \%$ pada tahun 2010 untuk kelompok diatas 15 tahun, karena prevalensi perokok perempuan turut meningkat dari $4,2 \%$ pada tahun 1995 menjadi 6,7\% pada tahun 2015. Data WHO (2015) menyatakan Indonesia sebagai 
pasar rokok tertinggi di dunisa setelah China dan India.

Prevalensi perokok laki-laki dewasa di Indonesia paling tinggi di dunia $(68,8 \%)$.

Data Kementerian Kesehatan menunjukan peningkatan prevalensi perokok dari $27 \%$ pada tahun 1995 meningkat menjadi $36,3 \%$ pada tahun 2015, prevalensi perokok pada usia lebih muda (16 -19 tahun) juga terjadi peningkatan 3 kali lipat. 69\% rumah tangga memiliki pengeluaran untuk rokok, rata-rata individu perokok menghabiskan Rp. 216.000 per bulan untuk membeli rokok. Penurunan kualitas dan produktivitas generasi penerus bangsa akibat mengkonsumsi rokok akan menghambat pembangunan (Ermalena, 2017). Hasil penelitian lain menunjukan bahwa nikotin dapat meningkatkan penggumpalan darah dalam pembuluh darah, selain nikotin juga dapat menyebabkan terjadinya pengapuran pada dinding pembuluh darah kondisi akan merangsang hipertensi karena adanya sintesa katekolamin yang dalam jumlah besar dapat memicu kenaikan tekanan darah (Grey, et al 2005). Mengutif hasil penelitian lain di Rumah Sakit Persahabatan Jakarta tahun 2013. Hasil penelitian juga menunjukan data bahwa rata-rata anak yang dilahirkan oleh ibu perokok memiliki berat badan yang lebih ringan $(<2500$ gram) dan lebih pendek $(<4,5 \mathrm{~cm})$ dibandingkan dengan anak yang dilahirkan oleh ibu bukan perokok (>3000 gram) dan lebih panjang $(>50 \mathrm{~cm})$, Akibat rokok di Indonesia menyebabkan $9.8 \%$ kematian karena penyakit paru kronik dan emfisema pada tahun 2011. Datadata tersebut menunjukan bahwa merokok jelas berakibat buruk terhadap kesehatan masyarakat Indonesia.

d. Penderita hipertensi melakukan pengobatan secara teratur

Hasil penelitian menunjukan bahwa capaian penderita hipertensi melakukan pengobatan secara teratur dicapai sebesar $74 \%$, dan terdapat penderita hipertensi yang tidak melakukan pengobatan sebesar 26\%. Data survey indikator kesehatan nasional (Sirkesnas) tahun 2016 menunjukkan adanya peningkatan prevalensi hipertensi pada penduduk usia 18 tahun ke atas sebesar 32,4\% (Kemenkes, 2016). Ketidaktahuan masyarakat umum mengenai sifat tekanan darah yang meningkat, efek mobiditas dan metode mempertahankan kontrolnya meluas dan berkontribusi terhadap persentase besar subjek hipertensi yang tidak terdeteksi dan tidak 
diobati di masyarakat. Dalam banyak kasus, tanda hipertensi pertama adalah serangan jantung tiba-tiba atau stroke, inilah sebabnya mengapa hipertensi sering disebut "silent killer". Menurut hasil penelitian yang dilakukan oleh Muthiah Vadugathan dkk tahun 2017, lebih dari 1 miliar orang dewasa di seluruh dunia (sekitar 25\%) menderita hipertensi dan diperkirakan akan meningkat menjadi 29\% pada tahun 2025. Penyakit tidak menular dapat dicegah melalui pengendalian faktor risikonya dengan upaya pelayanan yang berbasis promotif dan preventif. Menjadi penting dan harus dilakukan kajian/deteksi dini dan pemantauan faktor risiko dalam pengendalian hipertensi di masyarakat di berbagai wilayah (Mbouemboue, 2016\&Kemenkes 2015).

e. Bayi mendapatkan imunisasi dasar lengkap

Pencapaian indicator bayi mendapatkan imunisasi lengkap mencapai $82 \%$. Terdapat $18 \%$ bayi yang tidak mendapatkan imunisasi lengkap. Hal ini sejalan dengan penelitian yang dilakukan oleh Vivi Triana tahun 2015 tentang factor yang berhubungan dengan pemberian iunisasi dasar pada bayi yang menyatakan bahwa Hampir separuh responden yang tidak mendapakan imunisasi dasar lengkap, berpengetahuan rendah, memiliki sikap negatif, mendapatkan pelayanan imunisasi yang baik, tidak mengalami hambatan dalam memperoleh imunisasi, mempunyai moivasi dan informasi yang cukup tentang imunisasi. Variabel yang tidak mempunyai hubunan bermakna dengan pemberian imunisasi dasar lengkap adalah pendidikan orang tua, pekerjaan, pelayanan imunisasi dan hambatan orang tua sedangkan variabel pengetahuan, sikap. motivasi orang tua dan informasi imunisasi tidak memiliki hubungan yang signifikan dengan pemberian imunisasi dasar lengkap pada bayi di Kecamatan Kuranji Kota Padang tahun 2015. Peneliti menyarankan kepada tenaga kesehatan khususnya pemegang program imunisasi agar meningkatkan penyuluhan ruin kepada masyarakat terutama ibu yang memiliki bayi baik secara individu ataupun kelompok. Penyuluhan secara individu dapat dilaksanakan pada waku kegiatan imunisasi, sedangkan penyuluhan kelompok dapat dilaksanakan pada waktuwaktu tertenu sesuai dengan jadwal yang telah ditentukan. Penyuluhan juga dapat dilakuan dengan cara penyebaran leaflet, pemasangan poster maupun melalui media sosial. Materi penyuluhan yang 
dapat diberikan diantaranya adalah tentang arti pentingnya imunisasi, efek samping dari imunisasi serta kandungan dari imunisasi yang diberikan kepada bayi sehingga dapat mengubah anggapan negatif dari masyarakat tentang imunisasi. Selain itu tenaga kesehatan juga dapat melakukan pelatihan kader posyandu sehingga kader juga dapat melakukan penyuluhan kepada masyarakat

f. Keluarga mengikuti program KB Pencapaian indicator keluarga mengikutu keluarga berencana (KB) mencapai $84 \%$. Artinya masik terdapat anggota keluarga yang tidak mengikuti $\mathrm{KB}$ sebesar $16 \%$. ). Ketidak ikutsertaan responden dalam ber $\mathrm{KB}$ dalam penelitian ini disebabkan sedang dalam penantian memiliki keturunan. Undang-Undang Nomor 52 Tahun 2009 tentang Perkembangan Kependudukan dan Pembangunan Keluarga menyebutkan bahwa Keluarga Berencana adalah upaya mengatur kelahiran anak, jarak dan usia ideal melahirkan, mengatur kehamilan melalui promosi, perlindungan dan bantuan sesuai dengan hak reproduksi untuk mewujudkan keluarga berkualitas. Keluarga berencana dan keluarga sejahtera yang masuk ke dalam Peraturan Pemerintah No. 38 Tahun 2007 menjadi urusan wajib pemerintah yang diselenggarakan Pemerintah

Daerah Provinsi dan Pemerintah

Daerah Kabupaten/Kota, berkaitan dengan pelayanan dasar. Program KB Nasional salah satunya adalah Program KB \& Kesehatan Reproduksi (Maria, 2015n.

\section{KESIMPULAN}

Berdasarkan hasil analisis dapat disimpulkan sebagai berikut:

1. Pencapaian indikator keluarga sehat di Desa Saguling mencapai $75 \%$, artinya masih ada $25 \%$ keluarga yang tidak memiliki akses dan menggunakan jamban sehat.

2. Pencapaian keikutsertaan keluarga menjadi anggota JKN sebesar 55\%, dan $45 \%$ keluarga belum menjadi anggota JKN

3. Pencapaian indikator anggota keluarga tidak ada yang merokok dicapai sebesar 40\%, artinya 60\% anggota keluarga adalah perokok

4. Pencapaian penderita hipertensi melakukan pengobatan secara teratur dicapai sebesar 74\%, dan terdapat penderita hipertensi yang tidak melakukan pengobatan sebesar $26 \%$.

5. Pencapaian indicator keluarga mengikutu keluarga berencana (KB) mencapai $84 \%$. Artinya masik terdapat anggota keluarga yang tidak mengikuti KB sebesar $16 \%$.

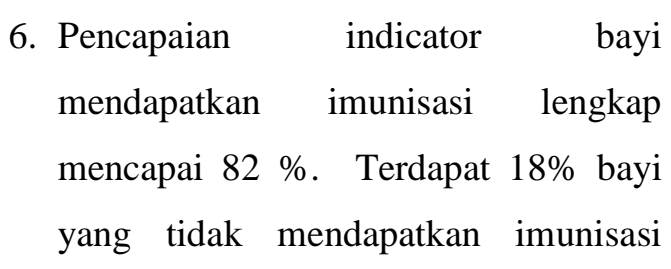


lengkap

\section{REFERENSI}

Azwinsyah, dkk. (2014). Faktor-Faktor yang Berhubungan dengan Rendahnya Kepemilikan Jamban Keluarga dan Personal Hygiene dengan Kejadian Diare di Desa Sei Musam Kendit Kecamatan Bahorok Kabupaten Langkat Tahun 2014.

Dharma. (2014). Faktor-Faktor yang Berhubungan dengan Rendahnya Kepemilikan Jamban Keluarga dan Personal Hygiene dengan Kejadian Diare di Desa Sei Musam Kendit Kecamatan

Bahorok Kabupaten Langkat Tahun 2014.

Fera Novitri \&Rizka Agustin, 2017. Determinan Kepemilikan Jamban Sehat di Desa Sukomulyo Martapura Palembang. Jurnal Aisyah:Jurnal Ilmu Kesehatan.2. (2), 107-116. ISSN 2502.9495

Gray, Huon H, Et Al. 2005. Lecture Notes : Kariologi Edisi Empat. Jakarta : Erlangga

Irwandy, 2015. Kajian Literatur: Evaluasi Pelaksanaan Program Jaminan Kesehatan Nasional di Indonesia. Jurnla Kebijakan Kesehatan Indonesia:JKKI. Vo. 5 No. 2 (2016)

Kemenkes RI, 2016. Pedoman Pelaksanaan Program Indonesia
Melalui Pendekatan Keluarga.

Jakarta

Kemenkes RI, 2016. Pedoman Penyelenggaraan Program Indonesia Sehat dengan Pendekatan Keluarga. Lampiran Peraturan Kementerian Kesehatan No. 39 tahun 2016

Muhadi, 2016. JNC 8.Evidence-Based Guidline Penangan Pasien Hipertensi Dewasa. Divi Kardiologi.Depatemen Ilmu Penyakit Dalam. FKUI.RS Cipto MAngunkusumo. Jakarta. Indonesia. CDK-236/Vol 43 No. 1 Tahun 2016.

Mbouemboue et al. 2016. A CommunityBased Assesment of Hyprtension and Some Other Cardiovascular Risk Faktor in Ngaoundere Cameroon.

HindawiPublishing Cooporation. International Journal

Hypertension. Volume 2016. Article ID 4754636.9 pages. Http://dx.doi.org/10.1155/2016/47 $\underline{54636}$

Maria,Aloysius \&Ari, 2015. Evaluasi

Program Keluarga Berencana dan Kesehatan Reproduksi Tentang Kasus Peran Serta Pria di Kecamatan Semarang Barat.Undip

Setiadi, 2008. Konsep dan Proses Asuhan Keperawatan Keluarga. Graha Ilmu:Jakarta ISSN: 9789797563264 
Jurnal Keperawatan Galuh

Volume : 1-Nomor : 1 Tahun : 2019

Suprajitno, 2016. Asuhan Keperawatan Keluarga Aplikasi Pada Praktik. EGC:Jakarta. ISSN: 979-448-6892

Vivi Tru=iana, 2015. Faktor Yang Berhubungan Dengan Pemberian Imunisasi Dasar Lengkap pada Bayi. Jurnal Kesehatan
Masyarakat Andalas. FKM Andalas:JKMA. p-ISSN 19783833 e-ISSN 2442-6725 10(2)123-135

WHO. (2014). Progres Sanitasi dan Air Minum - Progress on Sanitation and Drinking-Water: Update. Geneva: WHO 2010. 